\title{
La autotraducción y el original secundario en llan Stavans: ser traduciendo, traducirse para ser ${ }^{1}$
}

\author{
M. ${ }^{a}$ Carmen África Vidal Claramonte \\ africa@usal.es \\ http://orcid.org/0000-0002-0521-6906 \\ Universidad de Salamanca, España
}

\begin{abstract}
Resumen
El propósito de este artículo es analizar la función de la autotraducción en Ilan Stavans, un traductor y autotraductor muy influido por la teoría traductológica de Jorge Luis Borges. Mi punto de partida es que estamos ante un autor palimpséstico, dado su origen híbrido y su vida posmonolingüe. Ilan Stavans es un migrante judío, mexicano, latinoamericano que se mueve contantemente entre muchas lenguas, desde el hebreo hasta el inglés o el espanglish. Sus traducciones y autotraducciones demuestran esta interconexión entre espacios y lenguas. Stavans es un traductor traducido para quien, siguiendo al autor argentino, la traducción no es una actividad secundaria, sino que completa el original.
\end{abstract}

Palabras clave: autorretrato; autotraducción; identidad; Ilan Stavans; Jorge Luis Borges; traducción.

\section{Self-Translation and the Secondary Original in llan Stavans:}

To Be Translating, To Translate Oneself to Be

\begin{abstract}
The aim of this article is to show how self-translation works in Ilan Stavans' rewritings. Stavans is an acclaimed author, translator and self-translator who follows Jorge Luis Borges' ideas on translation. Ilan Stavans is a Jewish-Mexican-American polyglot who moves among Yiddish, Hebrew, English, Spanglish and Spanish. His translations show the contemporary interconnection between spaces and languages. Stavans is a palimpsest, since he is a hybrid and post-monolingual writer. He is a translated translator who argues, in line with Borges, that translation is not a secondary task but one that completes the original.
\end{abstract}

Keywords: self-portrait; self-translation; identity; Ilan Stavans; Jorge Luis Borges; translation.

1 Este artículo hace parte del proyecto de investigación: "Experiential Translation: Meaning-Making, Engagement and Agency across Media in a Multimodal World" (2021-2022) financiado por Arts and Humanities Research Council AHRC Research Grant, AH/V008234/1 
L'autotraduction et l'original secondaire chez llan Stavans:

être en traduisant, se traduire pour être

153

\section{Résumé}

L'objectif de cet article est d'analyser la fonction de l'autotraduction dans les réécrits d'Ilan Stavans, un traducteur et autotraducteur fortement influencé par les théories de Jorge Luis Borges sur la traduction. Ilan Stavans est un auteur palimpseste, étant donné son origine hybride et post-monolingue. Stavans est un migrant juif, mexicain, latino-américain qui se déplace parmi le yiddish, l'hébreu, l'anglais, le Spanglish et l'espagnol. Ses traductions et autotraductions montrent l'interconnexion contemporaine entre les espaces et les langues. Stavans est un traducteur traduit qui soutient, en ligne avec Borges, que la traduction n'est pas une activité secondaire, mais une tâche qui complète l'original.

Mots-clés : autoportrait; autotraduction; identité; Ilan Stavans; Jorge Luis Borges; traduction. 
Originality is a tricky business Ilan Stavans (2018a, p. 28)

Seguiré pintando el segundo cuadro, pero sé que no voy a acabarlo nunca [...] hasta un día, tarde o temprano, en que iré del primer cuadro al segundo y vendré luego a este texto, o saltaré la etapa intermedia, o interrumpiré una palabra para acercarme a poner una pincelada en la tela del retrato que $S$. me encargó, o en el otro, paralelo, que

$S$. no verá José Saramago (1977/1999, p. 9)

\section{Introducción}

La autotraducción es un fenómeno tan variado como apasionante y complejo. Variado, porque hay tantos tipos de autotraducción como autotraductores: véanse si no las diferentes reescrituras y sus múltiples funciones en autores como Ariel Dorfman, Esmeralda Santiago, Giannina Braschi, Rolando Hinojosa-Smith, Rosario Ferré o Valeria Luiselli, por citar solo unos cuantos nombres latinoamericanos. Apasionante y complejo, en tanto en él salen a la luz algunos de los conceptos más contemporáneos de la sociedad global cosmopolita. De ese modo, el autotraductor contemporáneo pone en jaque conceptos sobre los que durante mucho tiempo se ha sustentado la teoría de la traducción.

Así las cosas, este artículo empieza definiendo la autotraducción como un fenómeno político, como una metáfora que trasciende lo puramente textual, en tanto es un tipo de reescritura ligada a cuestiones absolutamente contemporáneas, como el exilio y la diáspora que (se) sustentan (en) la asimetría de poderes y que refleja las inquietudes de millones de identidades híbridas, fronterizas, en constante traducción. De esta forma, la autotraducción ya no significa alcanzar la equivalencia, sino incorporar la diferencia, lo extraño, lo global, pero también lo local, las perspectivas y los valores contrarios, para que se escuchen todas las voces, más allá de la tradicional concepción binaria de la traducción. La autotraducción es, en estos casos, algo inherente a la vida del original, que lo transforma para que este pueda sobrevivir.
Entendida de ese modo la autotraducción, en la segunda parte me centro en Ilan Stavans, porque, en mi opinión, es un (auto)traductor que ejemplifica perfectamente ese modo de ver la autotraducción. Stavans es un traductor con una ingente obra a sus espaldas, sobre cuyos ensayos, ficción y ediciones tanto se ha escrito ya: aparte de decenas de artículos académicos, hay ya varios libros que se adentran en su obra, entre ellos el de Steven G. Kellman, The Restless Ilan Stavans. Outsider on the Inside (2019b), y Stavans Unbound. The Critic Between Two Canons (2019a), editado por Bridget Kevane. Sin embargo, no hay apenas estudios sobre su teoría borgeana de la traducción y la autotraducción, el propósito de este artículo.

Stavans es más de uno; vive en lo que Emily Apter (2006) llama "zonas de traducción", en un espacio intermedio transnacional donde reaparece una y otra vez la relación entre lenguaje y poder, así como la idea de que el monolingüismo es una imposición política. Como traductor y autotraductor, Stavans representa a muchas personas que actualmente no viven en la lengua que los vio nacer, que están constantemente transitando de una lengua a otra y, lo que es más importante, traduciendo de una cultura a otra, de unos valores a otros.

Él mismo es una traducción: es traduciendo y se traduce para ser. Más que de traducción, habla de un segundo original, y cuando se autotraduce, aparece un tercer texto. Stavans es un palimpsesto creado a base de capas de culturas (la judía, la mexicana, la chicana, la estadounidense) y de lenguas (hebreo, yidis, español, espanglish, inglés).

Autotraductor, traductor al inglés de multitud de obras, y al espanglish, del Quijote, Hamlet, El Little Príncipe y Alicia en Wonderlandia, Stavans se define como un original secundario. Sus traducciones al espanglish reflejan su ser traducido, $\mathrm{su}(\mathrm{s})$ vida(s) en las grietas de las sílabas, en los huecos que se forman entre las palabras. Se autotraduce porque es una vida traducida, en constante traducción, en movimiento a través 
de las reescrituras que hace de sí mismo y de los demás. Así, se niega a que la lengua encaje con la geografía, en tanto quiere ocupar varios lugares y emplear varias lenguas. La autotraducción opera, en su caso, en el interior de las narrativas, en el interior del propio autotraductor, allí donde el espacio entre dos lenguas se convierte en un espacio de resistencia latente.

\section{Identidades autotraducidas: desde el otro lado del espejo}

En el mundo del arte, el autorretrato es una constante. Son famosos los de Tiziano, Durero, Leonardo, El Greco, Velázquez, Rembrandt, Van Gogh, Munch, Gauguin, Khalo, Picasso, Dalí. Pero no solo eso. Desde siempre, el artista ha reflexionado sobre el mundo a través de los espejos, fijándose en las representaciones de las representaciones, utilizando su propio yo como identidad traducida. El autorretrato del autorretrato enseguida trae a la mente el juego infinito que propone Parmigianino en su genial autorretrato de su autorretrato de 1524, donde juega con su propia imagen reflejada en un espejo. También el pintor que pinta al pintor que pinta en el cuadro de Vermeer de 1666, titulado El arte de la pintura. Y más allá del infinito juego semántico palimpséstico de Velázquez en su cuadro más famoso, que tan bien retrató Foucault (1966/1988) en su conocido ensayo sobre Las Meninas, incluido en Las palabras y las cosas viene a la mente su óleo de 1618 titulado Cristo en casa de Marta y María, donde la repetición, la imitación, los espejos y la reescritura son una espléndida reflexión sobre el concepto de representación $\mathrm{y}$, en consecuencia, sobre el de autotraducción.

En esta misma línea, cómo no recordar $L a$ galería del Archiduque Leopold en Bruselas (16541670) de David Teniers el Joven, o el autorretrato de Reynolds de 1747 , donde el yo pintado mira a quien está mirando el cuadro. Mucho más recientemente, la autorreflexión aparece en las fotografías que hace Man Ray de Rrose Sélavy (1921), a su vez una autotraducción de Marcel Duchamp (que además tiene su posterior reescritura en la obra de Yasumasa Morimura), en los malabarismos dentro de la foto de Alexander Rodchenko titulada Chauffeur (1933) o en los juegos con la identidad que denuncia Cindy Sherman en sus autofotografías.

Estos son solo unos cuantos casos que, como veremos, están en la línea de la manera de entender la autotraducción de Ilan Stavans en libros como On Self-Translation. Meditations on Language (2018a) o I Love My Selfie (2017), donde relaciona la autotraducción con los autorretratos, desde Rembrandt hasta Robert Mapplethorpe y Ana Mendieta, pasando por Magritte o Van Gogh.

Sin duda, también en la literatura la reflexión sobre el propio yo ha sido un tema recurrente, como sobre el ethos aristotélico entre identidad e impostura (Grutman, 2018a; Spoturno, 2019) y el clásico tema del doble, del Doppelgänger, desde Ernst Theodor Amadeus Hoffmann, Fiódor Dostoievski, René Albert Guy de Maupassant, Henry James, Robert Louis Stevenson, Gérard de Nerval, Oscar Wilde, Franz Kafka, Julio Cortázar o Raymond Queneau, hasta la reciente novela L'anomalie de Hervé Le Tellier. Así, Edgar Allan Poe, en su cuento "William Wilson" (1839) sobre el doble, o en su "Retrato oval" (1842), en el que la copia triunfa frente al original, que termina desapareciendo en favor de su representación; Oscar Wilde, en el Retrato de Dorian Gray, donde, como dice Basil, es lo secundario lo que se manifiesta; Susan Daitch, en $L$. $C$.; Jorge Luis Borges, en Siete noches, donde confiesa que el espejo es una de sus pesadillas; Virginia Woolf, en Orlando; Angela Carter, en The Passion of New Eve; Vladimir Nabokov, en Despair, Alain Robbe-Grillet, en su biografía titulada significativamente Le miroir qui revient; Carlos Fuentes en Aura; Peter Handke en $L a$ repetición, donde repetir no es volver atrás, sino volver a empezar. En todas ellas se juega con la diferencia y la repetición, conceptos sobre los que tan acertadamente reflexiona Deleuze (1968/1988), invitándonos a preguntar, como 
Funes el Memorioso, si necesitamos al autor para sobrevivir, o como Borges, en "Las versiones homéricas", cuál de los originales es el original.

Lo que quiero demostrar con estos ejemplos es que la autotraducción se da en otras disciplinas distintas a la nuestra, los estudios de traducción, y se entiende, al igual que lo hará Stavans, como un fenómeno mucho más complejo que la traducción interlingüística que un autor hace de su propia obra. Cual superficie reflectante, la autotraducción ha servido para revelar el original, pero también para ocultarlo. En autotraductores tan conocidos y analizados como Samuel Beckett, nos damos cuenta de que la equivalencia absoluta es una falacia, algo que, por otro lado, las teorías contemporáneas de la traducción, desde el giro cultural de Bassnett y Lefevere en 1990, hasta el "outward turn" de Bassnett y Johnston (el monográfico de la revista The Translator 25, 3, 2019), demostraron hace décadas, y esta idea será una constante, como veremos, en las traducciones y autotraducciones de Stavans. La autotraducción traduce las contradicciones del ser humano, sus emociones en las diferentes lenguas, su postura frente a los valores y poderes de otras culturas. Como leemos en la inscripción de un cuadro de Pieter Bruegel El Viejo, donde aparece un hombre mirándose en un espejo: "Nadie se conoce a sí mismo".

Con las autotraducciones de Ilan Stavans, veremos que el autotraductor se autoanaliza como original, pero que también inspecciona a su modelo, que no es para Stavans secundario, sino primario. Las traducciones $\mathrm{y}$ autotraducciones de Stavans escudriñan un juego que proyecta y refleja las identidades de quien mira y de quien es mirado, en un constante vaivén que al final hace que no sepamos muy bien en qué lado del espejo nos encontramos. El autotraductor objeto de estudio de este artículo actúa como Velázquez en Las Meninas: el pintor a punto de dar su primera pincelada; por eso mira atentamente al modelo. Para el espectador, el cuadro que pinta el autotraductor está de espaldas. Como espectadores, vemos el reverso de la reescritura. Desde dentro, el cuadro es visible para unos y no para otros, según donde estemos situados, y el pintor autotraductor es visto sobre el cuadro en el que se le representa, pero también en aquel en el que se ocupa de representar algo: reina, nos dice Foucault, en el umbral de estas dos visibilidades incompatibles. Lo que Velázquez plantea es un juego fascinante, una definición de la autotraducción como reverberación, un juego de representaciones y representados. El cuadro, como la autotraducción, es esa representación que se da como representación, y que ofrece el encanto doble de estar a mitad de camino entre el primer plano y el revés del tapiz (Foucault, 1966/1988, pp. 16, 25).

La autotraducción, como la entiende Stavans, nos remite a ese mundo que Borges presenta en su cuento "Animales de los espejos", donde la gente del espejo invade la tierra; donde no hay, igual que en el mundo de Alicia, fronteras infranqueables entre el original y su supuesta copia, entre nosotros y nuestros reflejos. Como el Emperador Amarillo borgeano, la autotraducción así entendida nos invita a repetir; pero no a repetir de una manera automática e irreflexiva, sino ingresando en un universo diferente, en un país de las maravillas que retorna necesariamente diferente en el (mismo) autor, que, como Alicia, no quiere reconocerse en el espejo.

Al emprender el camino por la senda mágica a través de la madriguera, traspasando el umbral del espejo, la realidad no es la misma, sino otra. En esa otra realidad, los valores que hicieron que el autor eligiese unas palabras en una cultura se ven trastocados en la otra y, en consecuencia, las palabras que escogerá para crear el texto no pueden sino verse igualmente metamorfoseadas.

En la casa del espejo de Alicia, la memoria funciona en ambos sentidos: todo es completamente igual y todo está completamente invertido. Con Alicia y el gato, el autotraductor 
nos invita a jugar a atravesar el espejo, siempre teniendo en cuenta que existe la posibilidad de perdernos, porque dos espejos opuestos forman un laberinto. El escritor se traduce a sí mismo como si fuera otro, el traductor escribe al otro como si fuera él mismo, temiendo descubrir, como en "La biblioteca de Babel" de Borges, su condición de mero simulacro:

No ser un hombre, ser la proyección del sueño de otro hombre iqué humillación incomparable, qué vértigo! [...]. Con alivio, con humillación, con terror, comprendió que él también era una apariencia, que otro estaba soñándolo (Borges, 1956/1986, pp. 68, 69).

Creo que la autotraducción es, como dice Saramago en Manual de pintura y caligrafia, encontrar lo que se perdió entre el primero y el segundo retrato (Saramago, 1977/1999, p. 49). Es ese momento, "en medio del movimiento" cuando "ya no estamos fuera y aún no estamos dentro" (p. 34), donde "el yo de este instante preciso es fundamentalmente diferente del que era un segundo antes, algunas veces lo contrario, pero, sin duda, siempre otro" (p. 52).

La autotraducción, según ejemplifica Ilan Stavans, es una nueva ocasión. Es aquello que reconocemos como familiar, pero que se dice por primera vez. Esto es especialmente notable, por razones muy variadas, en las autotraducciones de algunos escritores latinoamericanos, desde Ángela de Hoyos hasta Richard Blanco, muchas de ellas vidas traducidas que son, en sí mismas, una autotraducción (Hokeson y Munson, 2007).

Así, en el caso de Esmeralda Santiago, las sensaciones son diferentes en inglés y en español - según asegura en su prólogo a Cuando era puertorriqueña (1994)—, si bien es cierto que la actitud de esta autora hacia el inglés y el español y hacia el lector monolingüe ha ido cambiando desde esa novela hasta otras posteriores como America's Dream (véase Spoturno, 2016, 2018a, 2018b). O la situación y el espacio difieren, según Rolando Hinojosa-Smith, que decidió hacer sus propias traducciones, "recreaciones"
(Gentzler, 2008, pp. 146-147) de algunas novelas, que son, como en el caso de Estampas del Valle (1973) o Mi querido Rafa (1981), bastante diferentes de sus "originales" (Matelo y Spoturno, 2014).

Otro ejemplo interesante y diferente son las (polémicas) autotraducciones de Rosario Ferré, como la de Papeles de Pandora, que a tanta bibliografia han dado lugar (Castillo García, 2005, 2006, 2013; Henao, 2003; Hintz, 1995; Hokenson y Munson, 2007; Spoturno, 2018a, 2018b, 2019; Vidal, 2017).

Todos estos casos y muchos más dejan claro que, como se señaló al principio, la autotraducción es un fenómeno apasionante y complejo. Así, Ariel Dorfman, por ejemplo, el escritor chileno que, en una entrevista con Danny Poster publicada en The Progressive en 1998, describió su vida como "a trajectory of exiles", asegura llevar una vida doble, una vida traducida (Dorfman, 2002, 2004, 2005):

\footnotetext{
When you are bilingual in some ways you are constantly translating, or you are constantly taking into account the other language. I speak both English and Spanish like a native, though that is not entirely true. I speak each of them with a slight tolt or nod in the direction of the other. Each language is inhabited by the other [...] You cannot talk about this use of languages without also talking about two simultaneous conditions: one is the evolution of one's own identity as a dual person, very much related to the political and geographic place you occupy, and the other in the intervention of history. You don't just switch languages, you don't just switch countries. Behind it is the rush of history and, unfortunately a great deal of pain (Dorfman, 2002, p. 57).
}

Para él, como para tantos otros autotraductores, entre ellos Stavans, pasar a otra lengua significa pasar a otra cultura, a otros valores, a otro espacio. Y esto no es tarea sencilla, sino un acto político y vital que puede ser doloroso, como él mismo señala. El lenguaje es un ser vivo que no se conforma con la inmovilidad, 
sino que se transforma en esos espacios, en esas zonas de contacto:

Though what I finally arrived at was not the victory of one tongue over the other one but rather a cohabitation, my two languages reaching a truce in order to help the body they were lodged in to survive [...] it is as an adulterer of language that I presently trust that the distress of being double and somewhat homeless is overshadowed by the glory of being hybrid and open. It is as a fluid bigamist of language (Dorfman, 2003, p. 33).

Las lenguas, como quienes las hablan, son "maddeningly migrant", toman prestado "from here and there and everywhere", y consiguen, desde la extrañeza, desde la heterodoxia, "the most beautiful, the strangest, the most exciting objects", retorciendo las palabras y transformándolas "in a different wonderfully twisted and often funny guise, pawning those words, punning them, stealing them, renting them out, eating them, making love to them and spawning splendidly unrecognizable children" (Dorfman, 2003, p. 34).

De ese modo, el autotraductor contemporáneo pone en jaque conceptos sobre los que durante mucho tiempo se ha sustentado la teoría de la traducción, como los de agencia y autoridad (Bassnett, 2013; Grutman, 1998, 2009, 2018b; Grutman y Van Bolderen, 2014), la oposición binaria entre original y copia, primario y secundario, cultura fuerte y débil (Bujaldón et al., 2019; Castro et al., 2017).

La autotraducción es, pues, una reflexión sobre el concepto de identidad y sobre las nociones de primario y secundario, una renegociación del yo y una reescritura del sujeto (Anselmi, 2012); pero es, además, un fenómeno político, una reconceptualización del poder ligada a "tensions generated by geopolitical spaces where major and minorized cultures and nations collide, and a constant struggle for hegemony is met by different forms of resistance" (Castro et al., 2017, p. 11).
La autotraducción, como la traducción, trasciende lo puramente textual, en tanto es un tipo de reescritura ligada a cuestiones absolutamente contemporáneas, como el exilio y la diáspora, que (se) sustentan (en) la asimetría de poderes, y que refleja las inquietudes de millones de identidades híbridas, fronterizas, en constante traducción:

[...] moving freely between cultures, or having been forced into exile, the self-translator's stereolinguistic optics puts any one of her or his languages/cultures into relief with respect to the other. Consequently, self-translators share with many other writers from the margins the tendency to subvert the possibility that their writing affirms a singular national culture or literature. Indeed, the subject of the self-translated text is very often hybridity itself (Cordingley, 2013, p. 3).

La autotraducción es un proceso de descubrimiento, y acaso, a veces, de curación, pero siempre una reflexión sobre las heridas y las cicatrices de los vaivenes de la vida:

[...] self-translation is difficult and painful because it appears at first to expose gaps between languages, to raise the spectre of a divided mind and of a divided world, but when the translation is completed, the gaps are closed, the process has become a healing one and the self-translator is no longer caught between languages but able to exist fully in both (Bassnett, 2013, p. 16).

La autotraducción es, pues, el tipo de traducción que nos permite saber más de la identidad autoral migrante comprometida (o no), porque crea un nuevo original: "what is being negotiated is not only an 'original' text, and perhaps the self which wrote it, but the vexatious notion of 'originality' itself" (Cordingley, 2013, p. 3).

En todos los casos, estamos ante el ser humano duplicado que, como Tertuliano Máximo Afonso, se pregunta quién de los dos es el original, y que, sin embargo, concluye, al modo de Ilan Stavans, que ninguno de los dos es el 
original ni la repetición, sino que ambos son "la imagen real del que desde el espejo lo mira" (Saramago, 2002/2003, p. 232).

\section{La autotraducción como forma de vida: Ilan Stavans, ser traduciendo, traducirse para ser}

Ilan Stavans es un traductor, escritor, académico, editor, judío-americano-mexicano transmigrante (Nergaard, 2021), políglota, siempre en tránsito, que se define como una copia, como un eco, como una imitación, como alguien que siempre ha tenido la sensación de estar viviendo la vida de otro (Stavans, 2001, p. 262); alguien que no es uno, sino muchos,

You know, sometimes I have the feeling I'm not one but two, three, four people. Is there an original person? An essence? I'm not altogether sure, for without language I am nobody. Language makes us able to fit into a context. And what is there to be found in the interstices between contexts? Not silence, Richard-oh, no. Something far less compelling: pure kitsch (Stavans, 2002, p. 250).

Stavans "es" en función de la lengua en la que habita:

I have learned to live with the ackwardness of this situation. It has taught me that I have many selves, and that I negotiate these selves every time I choose to express myself in Spanish, Yiddish, Hebrew, or English. While writing On Borrowed Words, I came to believe that I lived in translation without an original. In the past decade and a half, I have come to refine that view: I exist in an echo chamber of self-translated voices, all of them my own (Stavans, 2018a, p. 10).

Se siente atraído por las máscaras (Stavans y Villoro, 2014, pp. 147-148), por ese revés del tapiz que don Quijote tanto denostaba (segunda parte, capítulo LXII), paradójicamente en una novela fruto de un manuscrito que pasa por varias manos: los ocho primeros capítulos pertenecen a un autor anónimo que deja de escribir porque "no halló más escrito, destas hazañas de don Quijote" (1, p. 89), tras el cual otro autor descubre que la historia aparece por primera vez escrita en árabe y le encarga a un morisco aljamiado que la traduzca, y quien por cierto lo hace dejando su huella en la traducción, como se reconoce en varios lugares, pero especialmente en los capítulos $\mathrm{v}$ y XXVII de la segunda parte. No en vano Douglas Robinson incluye, en su antología de 1997, Western Translation Theory, sobre teorías de la traducción en Occidente, un fragmento del mencionado capítulo LXII de la segunda parte del Quijote, por considerar que elabora una teoría de la traducción cuando reflexiona sobre el concepto de copia exacta.

En el Quijote, todo son traducciones y autotraducciones: el manuscrito de Cide Hamete, el traductor morisco, el segundo autor cristiano. Todo ello implica reescrituras no solo en cuanto a la lengua, sino también a valores culturales, religiosos, identitarios en un momento histórico en el que España rechazaba las influencias musulmana y judía. Las traducciones van desde la transformación del protagonista en caballero andante, hasta la de una bacía en yelmo mágico o unos molinos en gigantes. Stavans, a la manera del hidalgo, no se considera un original, sino una copia:

I am a copy, an instant replay, a shadow, an impostor. Everything is an echo. To live is to plagiarize, to imitate, to steal. I have always had the feeling of living somebody else's life (Stavans en Kellman, 2003, p. 122).

En su autobiográfica On Borrowed Words: $A M e-$ moir of Language (2002, p. 250), un libro que se escribió, "in translation without an original, that is to give my English a variety of accents" (Stavans, 2018, p. 6), Stavans se define como un autotraductor sin original, híbrido, a caballo entre lenguas y espacios. Stavans es muchas voces, es las lenguas que ama y que necesita: "Indeed, I believe in multiple loves" (Stavans, en De Courtivron, 2003, p. 145), porque vive traducido:

$\mathrm{U}$

r 
u

are

TÚ . . .

$\mathrm{Y}$

tú

eres

lumps,

various

(Stavans, 2018b, p. 36).

La autotraducción, como una constante, es algo que refleja la sociedad global, híbrida, transmigrante, en la que vivimos:

Ours is a universe infused with translations. From the conversation with a long-distance operator, a taxi driver, a tourist, and a newly-arrived immigrant, to the browsing of foreign channels on our cable network, the pleasure of a novel drafted in another language, to the debate on bilingual education and 'English Only' and 'English First' [...] ours is a universe inundated by translation. Increasingly, it is everywhere you go. Yet we are fixated on the fact that the degree of encounter in translation is dissatisfying, that something is always lost. It surely is, but, as far as I'm concerned, something is also won, so to speak. Who are we when we are translated? Has our self been adulterated, deformed, and reinvented? Might it have been improved, perhaps? (Stavans, en Sokol, 2004, p. 84).

Por eso, cuando traduce a esa lengua híbrida que es el espanglish, está en realidad autotraduciéndose, porque es en ese espacio intermedio entre dos lenguas, en esa zona de traducción y de contacto, donde él, como millones de personas actualmente, desarrolla su existencia cotidiana.

La elección de una lengua que existe en el tercer espacio (Bhabha, 1994) es un acto político contra "la patria desmadreadora" (Stavans, 2014, p. xiv) que es España, pero también contra el inglés como lingua franca:

¿Es el Spanglish una afronta al español? If so, qué bien. Does it represent its demise? De ninguna manera. ¿Debe el inglés preocuparse del amplio número de hablantes, unos cuarenta millones a nivel mundial? A Little (Stavans, 2020, p. 14).

En ese espanglish leemos su Quijote:

In un placete de La Mancha of which nombre no quiero remembrearme, vivía, not so long ago, uno de esos gentlemen who always tienen una lanza in the rack, una buckler antigua, a skinny caballo y un grayhound para el chase. A cazuela with más beef than mutón, carne choppeada para la dinner, un omelet pa los sábados, lentil pa los viernes, y algún pigeon como delicacy especial pa los domingos, consumían tres cuarers de su income. El resto lo employaba en una coat de broadcloth y en soketes de velvetín pa los holidays, with sus slippers pa combinar, while los otros días de la semana él cut a figura de los más finos cloths. Livin with él eran una housekeeper en sus forties, una sobrina not yet twenty y un ladino del field y la marketa que le saddleaba el caballo al gentleman y wieldeaba un hookete pa podear. El gentleman andaba por allí por los fifty. Era de complexión robusta pero un poco fresco en los bones y una cara leaneada y gaunteada. La gente sabía that él era un early riser y que gustaba mucho huntear. La gente say que su apellido was Quijada or Quesada but acordando with las muchas conjecturas se entiende que era really Quejada. But all this no tiene mucha importancia pa nuestro cuento, providiendo que al cuentarlo no nos separemos pa nada de las verdá (Stavans y Augenbraum, 2006, p. 23).

Esta traducción de Cervantes es una traducción de sí mismo y de la situación entre de millones de personas. Por eso, asegura Stavans que el acto de traducir simboliza la comunicación, el diálogo, el encuentro entre entidades dispares, y que cualquier reescritura es un intento de llegar al otro:

In other words, the translation act, in spite of such cultural abyss, cannot be discharged too easily. It's a necessity the modern world cannot afford to live without; it's an essential taste our intellectual life has gotten used to, 
the seasoning that keeps our cosmopolitan spirit afloat (Stavans, 1995, p. 33).

La autotraducción es actualmente, para muchas personas en continuo movimiento, un espacio donde habitar, un hogar en el que vivir, que no sustituye al original, sino que es una alternativa que lo complementa y lo enriquece. Por eso, Stavans reconoce que "When I translate, I'm at home" (Galasso y Stavans, 2021). $\mathrm{Su}$ yo traductor es en realidad el yo autor, y en ese sentido señala lo siguiente a propósito de la reciente publicación de sus Selected Translations. Poems 2000-2020 (2021):

To me, Selected Translations is a carte d'identité. This is one of my selves, perhaps the most important: I'm a translator. I live through translation and I translate in order to live. I'm an immigrant as well as a descendent of immigrants. Translation and immigration come hand in hand. To me the word "translation" is a synonym of home, or maybe homelessness. When I translate, I'm at home-mind you, a temporary home, never a fixed one. I know some of my homes better than others. What I like about them is that I'm a renter, not an owner. In other words, I'm always in transit. Another way of understanding translation is being alert to foreignness. I don't like the idea of translation as domestication. For me a text is like a stranger knocking at the door. I make the stranger be comfortable; I create a suitable atmosphere for the stranger to feel acclimated. But the stranger remains a stranger and mine the welcoming hand $[. .$. I find rereading far more rewarding than reading (en Galasso y Stavans, 2021).

No parece casual, pues, que Stavans sea autor de ensayos como On Self-Translation. Meditations on Language (2018) o I Love My Selfie (2017), mencionados anteriormente. En este último dedica un capítulo a los autorretratos en la pintura. A propósito de los casi cien autorretratos de Rembrandt, comenta que todos y cada uno de ellos son el mismo hombre y otro diferente, en tanto el yo autotraducido va cambiando a lo largo del tiempo y de los espacios. Los de Courbet y los de Van Gogh son autorretratos de sus mentes, y los de este último, a su vez, han sido reescritos por el arte pop (Stavans, 2017, p. 101). Los autorretratos de Magritte son una reescritura de la ausencia y del anonimato, pero también "about exposure and celebration" (Stavans, 2017, p. 102), como ocurre en Reproducción prohibida (1937), El plagio (1940) y La lección de anatomía (1943), que muestran la experiencia del doble, más allá de la semejanza. En la actualidad, el equivalente de los autorretratos serían los "selfies" y los "cellfies", a los que, por supuesto, Stavans ha dedicado algunas páginas (Stavans, 2017, p. 7; Vidal y Stavans, 2021).

Con Stavans nos encontramos ante un segundo original, y cuando se autotraduce, aparece un tercero:

En relación al concepto de "second original", esta opción, el Spanglish, actually prompts a third path: neither inglés nor español, crea una alternativa that we may want to call "tercer original". En mi propio caso, when I write a piece in casteñol — como lo hago ahora - it inhabits su propia estética and, para ser entendida en español o en inglés, it requires translation (Stavans, 2020, p. 14).

Como hicieran Parmigianino o Magritte sobre un lienzo, Stavans es un traductor traducido:

[...] he escrito cuentos en español que yo mismo have translated al inglés y que, when doing it, come out de forma distinta, con personajes diferentes y hasta endings that don't appear in the original. Confieso que a estas alturas I alone no sé cuál de las dos versiones es el original. In fact, prefiero un término utilizado originalmente por Singer: "second original". El autor que se auto-traduce se desdobla de tal manera que termina with two selves [...] El escritor que se auto-traduce exists en un permanente state of anxiety. En mi caso, I don't fully belong a la literatura mexicana o a la latinoamericana; in the United States, I am seen también como una rara avis. Es decir, ni soy de aquí or from the other side. Este sentimiento, obviamente, isn't new; de hecho, en un siglo en el cual migration is the dividing 
line, esta ansiedad is rather ubiquituous, o al menos es una constante acendente. To be dislocated, not to belong en ninguna parte, es ahora el sine qua non (Stavans, 2020, p. 14).

Es una identidad polifónica:

Mexican-American, and (in my case) Jewish-Mexican-American. We are a part of this country, yet separate from it; we're a part of the collective American we, but also proud owners of the fragmented American I. Our heritage is complex and sometimes confusing, but then so is the history of this nation we've come to call home (Stavans, 2014, p. Xv).

En su caso, multilingüismo es la capacidad de existir en varios mundos a la vez (Stavans, 1995 , p. 36). Y la autotraducción es una constante en esos mundos.

Esta manera de entender la autotraducción siempre me ha recordado la de Borges:

Al otro, a Borges, es a quien le ocurren cosas [...]. Me gustan los relojes de arena, los mapas, la tipografía del siglo xvIII, las etimologías, el sabor del café y la prosa de Stevenson; el otro comparte esas preferencias, pero de un modo vanidoso que las convierte en atributos de un actor. Sería exagerado afirmar que nuestra relación es hostil; yo vivo, yo me dejo vivir, para que Borges pueda tramar su literatura y esa literatura me justifica. Nada me cuesta confesar que ha logrado ciertas páginas válidas, pero esas páginas no me pueden salvar, quizá porque lo bueno ya no es de nadie, ni siquiera del otro, sino del lenguaje o de la tradición. Por lo demás yo estoy destinado a perderme, definitivamente, y sólo algún instante de mí podrá sobrevivir en el otro. Poco a poco voy cediéndole todo, aunque me consta su perversa costumbre de falsear y magnificar [...]. Yo he de quedar en Borges, no en mí (si es que alguien soy), pero me reconozco menos en sus libros que en muchos otros [...]. Hace años yo traté de librarme de él y pasé de las mitologías del arrabal a los juegos con el tiempo y con lo infinito, pero esos juegos son de Borges ahora y tendré que idear otras cosas. Así mi vida es una fuga y todo lo pierdo y todo es del olvido, o del otro.

No sé cuál de los dos escribe esta página (Borges, 1960/1989a, p. 186).

Este breve relato es, en mi opinión, una de las mejores definiciones que existen de la autotraducción. Es más, creo que Stavans estaría de acuerdo con lo que Borges dice sin decir. El espejo, la duplicación, la traducción, nos dan miedo por si adquieren vida propia y acaban por crear la realidad. Y, además, nos aterra pensar que bastan dos espejos opuestos para construir un laberinto (Borges, 1980a/1989, p. 226). Nos hemos acostumbrado a los espejos, dice Borges, pero hay algo de terrible en esa duplicación.

Lejos de las ideas de Pierre Menard sobre la traducción, Borges repitió una y otra vez que no es un problema que la novela española por excelencia, esa que es el origen de todas las demás, proceda, tal vez, de una traducción hecha por un mentiroso, como tampoco es un problema que su maravillosa historia "Tlön, Uqbar, Orbis Tertius" tenga su origen en la conjunción de un espejo y de una enciclopedia que es, a su vez, una reimpresión pirata de la Británica.

\section{Conclusiones}

Ninguna autotraducción, al igual que ninguna traducción, puede ser fiel al original, porque cada una lo enriquece, como una lectura nueva en un cuerpo diferente. Por el contrario, nos invita a cuestionar nuestro lugar como traductores, como reescritores, pero también el estatus de los textos originales y la autoridad de los autores. En la Biblioteca borgeana no hay dos libros idénticos, porque cada texto tiene diferentes modos de existir imbuidos en el espacio, el tiempo y la sociedad. El original es infiel a la traducción, dice Borges, y retoma Stavans (1989/1996, p. 187). El original "ought to be read as if written already in translation -a translation without an original" (Stavans, 2002, p. 88). La traducción supera al original, porque plantea la fractura referencial contemporánea, 
la representación como el punto donde el signo es el origen de otro signo. Cada autotraductor crea sus precursores. Como en "Las versiones homéricas", la primera vez es ya la segunda.

En su ensayo sobre las traducciones de Las mil y una noches, Borges (1980b/1989) nos recuerda que es ese un libro cuyo origen, como en el caso del Quijote, no es claro, y cuya autoría tampoco, La razón es que se trata de generaciones de autores que durante siglos han ido contando una serie infinita de cuentos que a su vez están dentro de un vasto relato central, el del sultán engañado por su mujer, que, para evitar que el engaño se repita, decide desposarse cada noche y hacer matar a la mujer a la mañana siguiente. Las traducciones de Las mil y una noches son muy diferentes entre sí, porque cada traductor ofrece su versión del libro. Así, nos relata el modo en que cada traductor corta, amplía, manipula y falsifica el original, para adecuarlo a su propia ideología y a la del público receptor, y es curioso cómo a él las traducciones que más le interesan son precisamente las menos equivalentes. Por ejemplo, habla de un famoso cuento, el de "Aladino y la lámpara maravillosa", del que no se ha encontrado el original, y a Borges poco le preocupa, porque considera que el traductor tiene tanto derecho a añadir historias como los cuentistas originales:

Hay un cuento que es el más famoso de Las 1001 noches y que no se lo halla en las versiones originales. Es la historia de Aladino y la lámpara maravillosa. Aparece en la versión de Galland y Burton buscó en vano el texto árabe o persa. Hubo quien sospechó que Galland había falsificado la narración. Creo que la palabra "falsificar" es injusta y maligna. Galland tenía tanto derecho a inventar un cuento como lo tenían aquellos confabulatores nocturni. ¿Por qué no suponer que después de haber traducido tantos cuentos, quiso inventar uno y lo hizo? (Borges, 1980a/1989, p. 240).

Son todas estas reflexiones borgeanas las que influyen en Ilan Stavans para construir su teoría de la traducción y de la autotraducción. La autotraducción nos sitúa, según Stavans, delante de nosotros mismos. Y tal vez sea por eso por lo que a veces causa desasosiego:

¿Por qué nos inquieta que el mapa esté incluido en el mapa y las mil y una noches en el libro de Las Mil y Una Noches? ¿Por qué nos inquieta que Don Quijote sea lector del Quijote, y Hamlet espectador de Hamlet? Creo haber dado con la causa: tales inversiones sugieren que si los caracteres de una ficción pueden ser lectores o espectadores, nosotros, sus lectores o espectadores, podemos ser ficticios (Borges, 1954/1989, p. 47).

Acaso por esas continuas y sanas paradojas y contradicciones en su identidad, Stavans, traductor y autotraductor, señaló en una ocasión que, a pesar de disfrutar de la autotraducción, en ocasiones no la recomienda:

For a simple reason: the translator is the closest reader a text might ever get. Indeed, in time the translator knows the author's subterfuges better than the author himself. This is because some of those subterfuges are unconscious, so the author isn't aware of them. By translating your own work, you deprive yourself of the closest reader you might otherwise be entitled to. Plus, every translation approaches the original as if it were sacred. This is a good place to explain a word I used in one of your previous questions: profane. If the original is sacred (that is, untouchable, irreplaceable, a source of awe), the translation is touchable, replaceable, a source of laughter. Whenever I translate myself, I feel the urge to change the original. Or I depart from that original by adding characters, inserting scenes, changing the ending: in short, I make the translation another original (Stavans, en Kellman, 2013, p. 11).

Estas palabras son, en mi opinión, toda una teoría borgeana de la autotraducción, una teoría, sin duda, muy recomendable, porque sitúa la autotraducción en el mundo contemporáneo, allí donde la labor traductora no es sino reflejo de esas vidas cotidianas que están en 
constante traducción, entre mundos, culturas y valores diferentes.

Hemos visto en este artículo la autotraducción como una metáfora (Grutman y Van Bolderen 2014) que nos permite reinventarnos al cambiar de lengua. Nos anima a ser bígamos de las lenguas en constante traducción (Dorfman, 2002, pp. 55 y 57). La autotraducción se ubica en espacios con personas siempre en tránsito, donde la intersección entre lenguaje, topos e identidad no es ni mucho menos fácil, sino que genera extrañeza, pero que también nos enriquece, porque, lejos de la univocidad, el espacio contemporáneo de la autotraducción es un Aleph donde es posible encontrar todas las lenguas, todas las identidades, un espacio no dicotómico que incluye, en cambio, todas las culturas y sus perspectivas, y donde, claro está, todos somos (auto)traductores.

\section{Referencias}

Anselmi, S. (2012). On self-translation. An exploration in self-translators teloi and strategies. LED Edizioni Universitarie.

Apter, E. (2006). The translation zone. A new comparative literature. Princeton University Press.

Bassnett, S. (2013). The self-translator as rewriter. En A. Cordingley (Ed.), Self-translation: Brokering originality in hybrid culture (pp. 13-26). Bloomsbury.

Bhabha, H. (1994). The location of culture. Routledge.

Borges, J. L. (1954/1989). Magias parciales del Quijote. En Otras inquisiciones. Obras completas (pp. 45-47). Emecé.

Borges, J. L. (1956/1986). La Biblioteca de Babel. En Ficciones (pp. 89-100). Alianza.

Borges, J. L. (1960/1989). Borges y yo. En El hacedor. Obras completas (p. 186). Emecé.

Borges, J. L. (1980a/1989). La pesadilla. En Siete noches. Obras completas (pp. 221-231). Emecé.

Borges, J. L. (1980b/1989). Las mil y una noches. En Siete noches. Obras completas (pp. 232-241). Emecé.
Bujaldón de Esteves, L., Bistué, B. y Stocco, M. (Eds.). (2019). Literary self-translation in Hispanophone contexts. Europe and the Americas. Palgrave.

Castillo García, G. (2005). Entrevista a Rosario Ferré: In between dos worlds. Centro Journal, 17(2), 233-247.

Castillo García, G. (2006). La (auto)traducción como mediación entre culturas. Servicio de Publicaciones Universidad de Alcalá.

Castillo García, G. (2013). Rosario Ferré y la (auto) traducción: (re)writing en inglés y en español. Servicio de Publicaciones Universidad de Alcalá.

Castro, O., Mainter, S. y Page, S. (Eds.). (2017). Self-translation and power. Palgrave.

Cordingley, A. (2013). Introduction: Self-translation, going global. In A. Cordingley (Ed.), Self-translation: Brokering originality in hybrid culture (pp. 1-10). Bloomsbury.

De Courtivron, I. (2003). Lives in translation. Bilingual writers on identity and creativity. Palgrave.

Deleuze, G. (1968/1988). Diferencia y repetición (Trad. Alberto Cardín). Ediciones Júcar.

Dorfman, A. (2002). Resisting hybridity. En D. Balderston y M. E. Schwartz (Eds.), Voice-overs. Translation and Latin American Literature (pp. 55-57). Albany: State University of New York Press.

Dorfman, A. (2003). The wandering bigamists of language. En I. de Courtivron (Ed.), Lives in translation. Bilingual writers on identity and creativity. (pp. 29-37). Palgrave Macmillan.

Dorfman, A. (2004). Footnotes to a double life. En W. Lesser (Ed.), The genius of language (pp. 206217). Anchor Books.

Dorfman, A. (2005). Life in translation. En I. Stavans (Eds.), Conversations with Ilan Stavans (pp. 52-61). The University of Arizona Press.

Foucault, M. (1966/1988). Representar. En Las palabras y las cosas (Trad. Elsa Cecilia Frost) (pp. 53-82). Siglo XXI.

Galasso, R. y Stavans, I. (2021). Translation as home: A conversation with Ilan Stavans. Latin American Literature Today, (17).

Gentzler, E. (2008). Translation and identity in the Americas. New directions in translation theory. Routledge. 
Grutman, R. (1998). Auto-translation. In M. Baker (Ed.), Routledge encyclopedia of translation studies (pp. 7-20). Routledge.

Grutman, R. (2009). Self-translation. In M. Baker and G. Saldanha (Eds.), Routledge encyclopedia of translation studies (pp. 257-260). Routledge.

Grutman, R. (2018a). The self-translator as author. Modern self-fashioning and ancient rhetoric in Federman, Lakhous and De Kuyper. En J. Woodsworth (Ed.), The fictions of translation (pp. 15-30). John Benjamins.

Grutman, R. (2018b). Translation that dare not speak its name: Amara Lakhous as an ambivalent self-translator. The Translator. https://doi. org/10.1080/13556509.2018.1527119

Grutman, R. y Van Bolderen, T. (2014). Self-Translation. In S. Bermann y C. Porter (Eds.), $A$ companion to translation studies (pp. 323-332). Wiley-Blackewell.

Henao, E. B. (2003). The colonial subjects's search for nation, culture, and identity in the works of Julia Alvarez, Rosario Ferré, and Ana Lydia Vega. The Edwin Mellen Press.

Hintz, S. (1995). Rosario Ferré, a search for identity. Peter Lang.

Hokeson, J. W., y Munson, M. (2007). History and theory of literary self-translation. St. Jerome.

Kellman, S. (2003). Switching languages. Translingual writers reflect on their craft. University of Nebraska Press.

Kellman, S. (2013). Translating Rulfo: A conversation with Ilan Stavans. Translation Review 86(1), 1-11. https://doi.org/10.1080/07374836.2013. 812376

Kellman, S. (2019a). Stavans unbound. The critic between two canons. Academic Studies Press.

Kellman, S. (2019b). The restless Ilan Stavans. Outsider on the inside. University of Pittsburgh Press

Matelo, G. y Spoturno, M. L. (2014). Acerca del fenómeno de la autotraducción en la obra de Rolando Hinojosa. Hermèneus, (16), 209-232. https://recyt.fecyt.es/index.php/HS/article/ view $/ 33273$

Nergaard. S. (2021). Translation and transmigration. Routledge.
Saramago, J. (1977/1999). Manual de pintura y caligrafia (Trad. Basilio Losada). Alfaguara.

Saramago, J. (2002/2003). El hombre duplicado (Trad. Pilar del Río). Alfaguara.

Sokol, N. (2004). Ilan Stavans: Eight conversations. The University of Wisconsin Press.

Spoturno, M. L. (2016) "Subjetividad, identidades de género y autotraducción. América's Dream y El sueño de América de Esmeralda Santiago". Revista académica liLETRAd, $\mathrm{N}^{\circ} 2,825-836$.

Spoturno, M. L. (2018a). "La construcción discursivo-enunciativa de las identidades culturales en When I Was Puerto Rican y Cuando era puertorriqueña de Esmeralda Santiago". En M. L. Spoturno, (Coord.), Escrituras de minorías, heterogeneidad y traducción (pp. 165-189). Universidad Nacional de La Plata.

Spoturno, M. L. (2018b). Self-retranslation as a rite of passage: Rosario Ferré's English version of "La muñeca menor". Mutatis Mutandis, 11(2): 356-375. https://revistas.udea.edu.co/index.php/mutatismutandis/article/download/335079/20792232/

Spoturno, M. L. (2019). El retrabajo del ethos en el discurso autotraducido. El caso de Rosario Ferré. Hermēneus, (22), 323-354. https://doi. org/10.24197/her.21.2019.323-354

Stavans, I. (1989/1996). Art and anger. Essays on politics and the imagination. Palgrave.

Stavans, I. (1995). The original language. Translation Review, 48-49(1), 33-37.

Stavans, I. (2001). The inveterate dreamer. Essays and conversations on Jewish culture. University of $\mathrm{Ne}-$ braska Press.

Stavans, I. (2002). On borrowed words. A memoir of language. Penguin.

Stavans, I. (2014). A most imperfect union. A contrarian history of the United States. Basic Books.

Stavans, I. (2017). I love my selfie. Duke University Press.

Stavans, I. (2018a). On self-translation. Meditations on language. State University of New York Press.

Stavans, I. (2018b). The wall. University of Pittsburg Press. 
Stavans, I. (2020). Self-translation como survival mecanismo. Ínsula (285): 13-15.

Stavans, I. (2021). Selected translations. Poems 20002020. University of Pittsburgh Press.

Stavans, I. y Augenbraum, H. (Eds.). (2006). Lengua fresca. Latinos writing on the edge. Mariner.

Stavans, I. y Villoro, J. (2014). El ojo en la nuca. Anagrama.
Vidal, M. C. Á. (2017). "Dile que le he escrito un Blues". Del texto como partitura a la partitura como traducción en la literatura latinoamericana. Vervuert Iberoamericana.

Vidal, M. C. Á. y Stavans, I. (2021). On memes as semiotic hand-grenades. A conversation. En T. King Lee y D. Wang (Eds.), Translation and social media communication in the age of the pandemic. Routledge.

Cómo citar este artículo: Vidal Claramonte, M. C. A. (2022). La autotraducción y el original secundario en Ilan Stavans: ser traduciendo, traducirse para ser. Mutatis Mutandis, Revista Latinoamericana de Traducción, 15(1), 152-166. https://doi.org/10.17533.udea.mut.v15n1a09 